\title{
Tendo Achillis pain: steroids and outcome
}

\author{
M. T. F. Read MA, MRCGP and S. G. Motto BM, DipSportsMed \\ Sport and Fitness, London Bridge Hospital, London, UK
}

\begin{abstract}
A retrospective study is presented of 83 athletes with tendo Achillis pain (TAP) treated conservatively over a 12-year period from 1976 to 1988 . Local steroid injections did not contribute to an earlier return to sport, though many individuals were improved symptomatically. Local steroids were not found to have a deleterious effect on outcome. Steroids were used most frequently in the chronic cases that presented late and had been treated previously: this group had most recurrences and surgical intervention. One case of Achilles rupture (3\%) occurred in the group treated with steroids. Early presentation for treatment led to an earlier return to sport and avoidance of recurrences. Recurrences were most frequent in athletes with bilateral Achilles tendinopathy.

The tendo Achillis lesion may range from peritendinitis through a mixed lesion of the tendon and paratenon, to complete rupture. The management depends upon accurate diagnosis, its chronicity and the age and aspirations of the patient. Steroids are safe to use and further prospective trials should note presentation time and disease staging accurately.
\end{abstract}

\section{Keywords: Achilles injuries, local steroid injections}

Achilles tendon ruptures may occur de novo ${ }^{1-3}$ or as a complication of chronic tendinopathy without local steroid injections ${ }^{1-4}$ and the causes seem to be multifactorial. However, there is a range of pathologies associated with tendo Achillis pain (TAP) ${ }^{5}$. These are not always clinically distinguishable but histological differences suggest that their treatment should be different. There may be a continuum from pure peritendinitis to total rupture ${ }^{3}$ and it has been impossible to distinguish in what proportion damage to the paratenon and epitenon (peritendinitis) and damage to the tendon (tendinosis) exist in combined lesions until surgery. Magnetic resonance imaging may be helpful.

Artificial lesions in animal studies do not totally reflect human responses as, for example, the reparative process in rat muscle is twice as fast as in humans ${ }^{6}$, and the half-life of steroids varies between

Address for correspondence: M. T. F. Read, Sport and Fitness, London Bridge Hospital, 27 Tooley Street, London SE1 2PR, UK (C) 1992 Butterworth-Heinemann Ltd 0306-3674/92/010015-07 species. This study looks at a number of cases of Achilles lesions treated non-surgically with or without steroids but has not been able to differentiate accurately between the lesions.

\section{Methods}

A retrospective study was carried out on 83 athletes with TAP who presented to the same physician at three sports and orthopaedic medicine clinics from January 1976 to September 1988.

\section{Assessment}

A history of pain in the morning, getting better with exercise or over the day but worse on resting, was classified as peritendinitis; whereas discomfort getting worse over the day or with exercise indicated tendinitis. Severity of the lesion was judged by pain on resisted movements and the hopping test: the number of hops possible on the affected side before the onset of pain, $0-10$ hops indicating severe injuries, $>10$ hops indicating less severe injuries.

\section{Exercise}

All cases were rested from running until 50 hops were accomplished without pain and then a running rehabilitation ladder ${ }^{7}$ was followed (Figure 1). It was not possible to oversee the ladder and several athletes jumped stages too rapidly. No one was classified as recovered unless he was match fit for his previous sport. Fitness before running was maintained by swimming, cycling or rowing machine routines. Stretching plus heel raises on the staircase to the pain threshold were encouraged for triceps surae flexibility and strength.

\section{Treatment}

Physiotherapy consisted mainly of ultrasound and cross-frictional massage, with some laser therapy to the tender area of the Achilles tendon.

Steroid injection $1.0-1.5 \mathrm{ml}$ hydrocortisone acetate $25 \mathrm{mg} / \mathrm{ml}$ (Boots Hydrocortistab, Boots, Nottingham, UK) plus $1.0 \mathrm{ml}$ local anaesthetic, either procaine or lignocaine $1-2 \%$, was given into the paratenon. The 23-guage needle was inserted parallel to the tendon fibres and gentle pressure applied to the plunger. If the needle was in the tendon, the injection would not flow and the needle was withdrawn until the fluid 


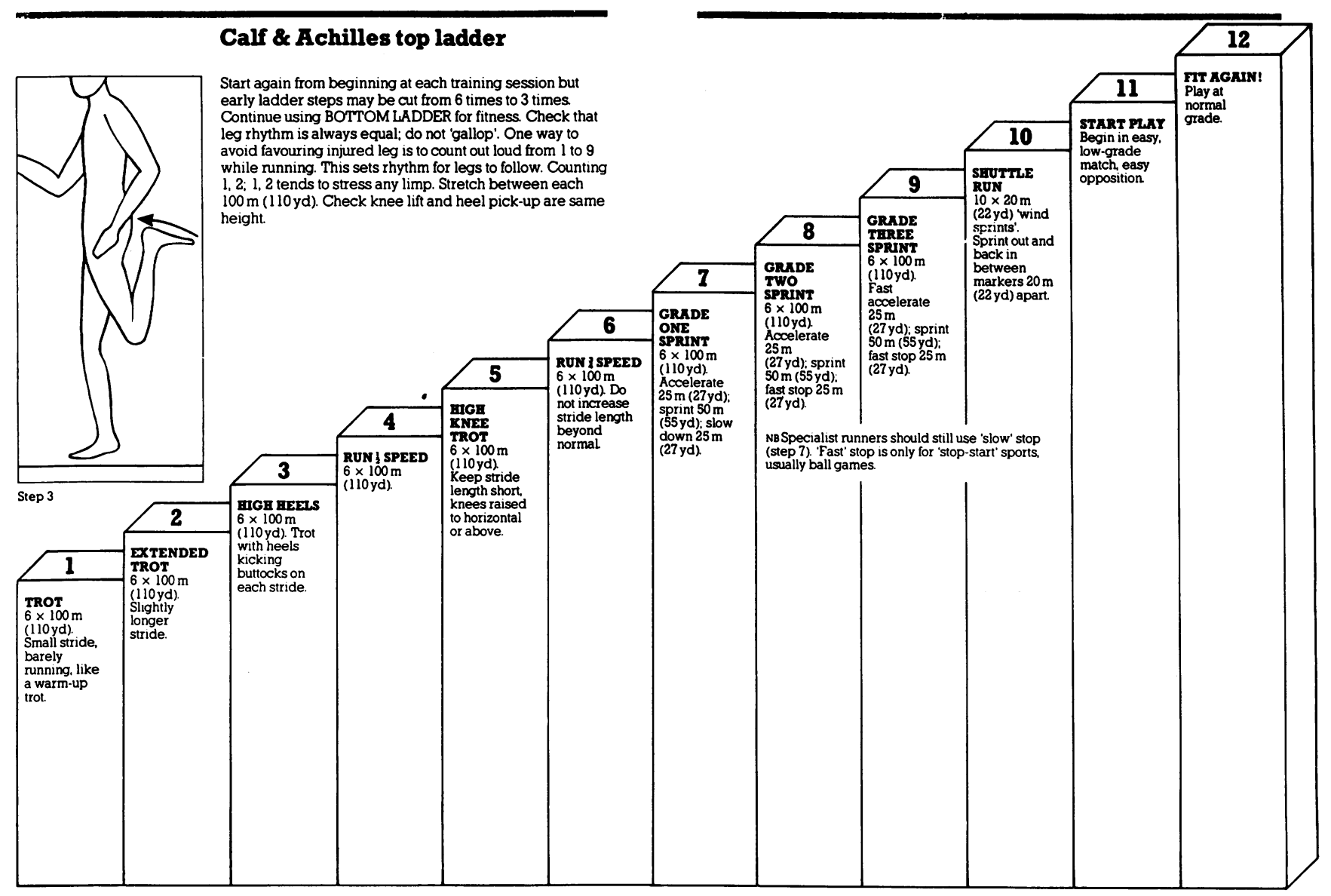

Figure 1. Running rehabilitation ladder. Reproduced, with permission, from Read M, Wade P. Sports Injuries. London: Breslich and Foss, 1984

flowed. The injection was placed over the tender areas usually laterally and anteriorly.

A follow-up period of 32 weeks was achieved in most cases.

\section{Results}

Over a 12-year period changes would be expected in medical practice, shoe design, training intensity and ages for participation in sport with an increase in both novice and veteran runners ${ }^{8,9}$.

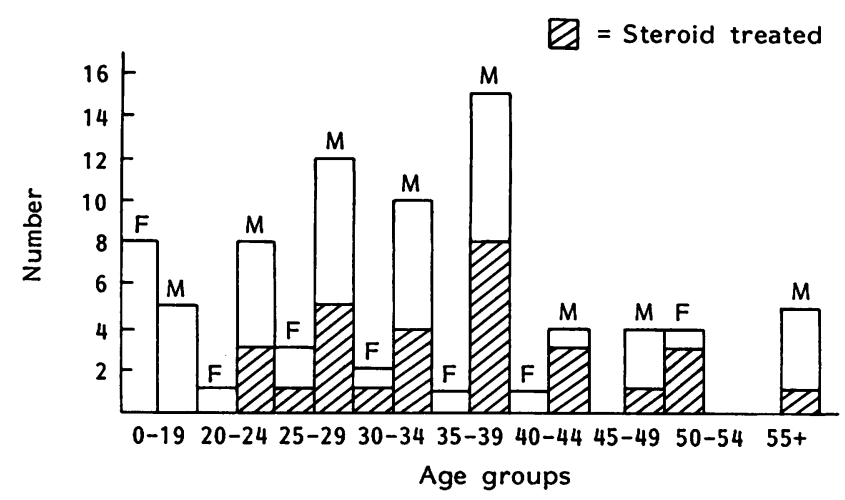

Figure 2. Age and sex distribution of the athletes, showing those treated with local steroid injections: $M$, male; $F$, female. Average age(s.d.) 32.5(12.5) years

\section{Age and sex}

The 83 athletes comprised 63 men, mean age 34 years (range 12-60), and 20 women, mean age 29 years (range 12-49). The mean age of the athletes in this study ( 32.5 years) is younger than that in earlier studies 5,10 , most of which record the mean age for tendon rupture as 34-44 with two peaks at 30-35 and 45-50 years ${ }^{11}$, whereas this paper records tendinopathies and fits more with the active group of Nillius ${ }^{12}$. The detailed age distribution is shown in Figure 2. Histological studies do not relate Achilles tendinopathies to ageing ${ }^{13,14}$.

The male to female ratio in this study was 3:1 whereas ruptures are reported ${ }^{15,16}$ range 4-10:1.

\section{Presentation (Table 1)}

The patients presented as acute, subacute or chronic cases, as shown in Figure 3, against time to recovery. There was recovery on a conservative regimen of many cases that presented after 6 weeks without resort to surgery, as suggested by Clancy ${ }^{17}$.

\section{Inactivity}

This paper adds no information to that established by Arner and Lindholm ${ }^{18}$ and Hooker ${ }^{19}$ and confirmed by Barfred ${ }^{1}$ that an increased incidence of rupture occurred in the physically inactive and that exercise 
Table 1. Clinical details on presentation

\begin{tabular}{|c|c|}
\hline $\begin{array}{l}\text { Initial clinical diagnosis } \\
\text { Tendinitis (T) } \\
\text { Peritendinitis (PT) } \\
\text { Mixed lesions (PT/T) } \\
\text { No clear diagnosis (?) }\end{array}$ & $\begin{array}{r}5 \\
17 \\
54 \\
7 \\
n=83\end{array}$ \\
\hline $\begin{array}{l}\text { Side of lesion } \\
\text { Right } \\
\text { Left } \\
\text { Both } \\
\text { (side not recorded in } 4 \text { cases) }\end{array}$ & $\begin{array}{r}24 \\
36 \\
19 \\
n=79\end{array}$ \\
\hline $\begin{array}{l}\text { Severity of the lesion } \\
\text { (assessed by the 'hop test') } \\
\text { Severe ( } 0-10 \text { hops) } \\
\text { Mild ( }>10 \text { hops) } \\
\text { (lack of data in } 17 \text { cases) }\end{array}$ & $\begin{aligned} & 38(58 \%) \\
& 28(42 \%) \\
n= & 66\end{aligned}$ \\
\hline $\begin{array}{l}\text { Presentation to clinic }{ }^{17} \\
\text { Acute }(<2 \text { weeks) } \\
\text { Subacute }(2-6 \text { weeks) } \\
\text { Chronic }(>6 \text { weeks) } \\
\text { of whom }<6 \text { months } \\
6-12 \text { months } \\
>1 \text { year } \\
\text { (lack of data in } 7 \text { cases) }\end{array}$ & $\begin{array}{c}3(4 \%) \\
18(24 \%) \\
55(72 \%) \\
29(38 \%)) \\
12(16 \%) \\
14(18 \%) \\
n=76\end{array}$ \\
\hline
\end{tabular}

strengthens the tendons, though this principle guides the rehabilitation ladders ${ }^{7}$ used in treatment. It is also important that rehabilitation loads should only be increased at the rate of tissue healing, i.e. graded against pain onset, and the one recorded rupture in this series broke this principle. Many authors suggest sudden increase in loads to be a major factor in Achilles disease ${ }^{20,21}$.

\section{Obliquity of loading}

Barfred ${ }^{1}$ indicated that the rotation of the tendon and its proportion of plaited, as opposed to interdigitating, fibres may not withstand transverse plane movements as well as anteroposterior movements. This may account for the improvement noted in some cases with corrective orthoses which decreased pronation 22,23 . During this 12-year period some patients used or were prescribed orthoses but the retrospective data did not allow for this analysis.

\section{Laterality (Table 2)}

In most reports, left-sided ruptures are more common than right ${ }^{24}$. Read and Bellamy ${ }^{25}$ have indicated

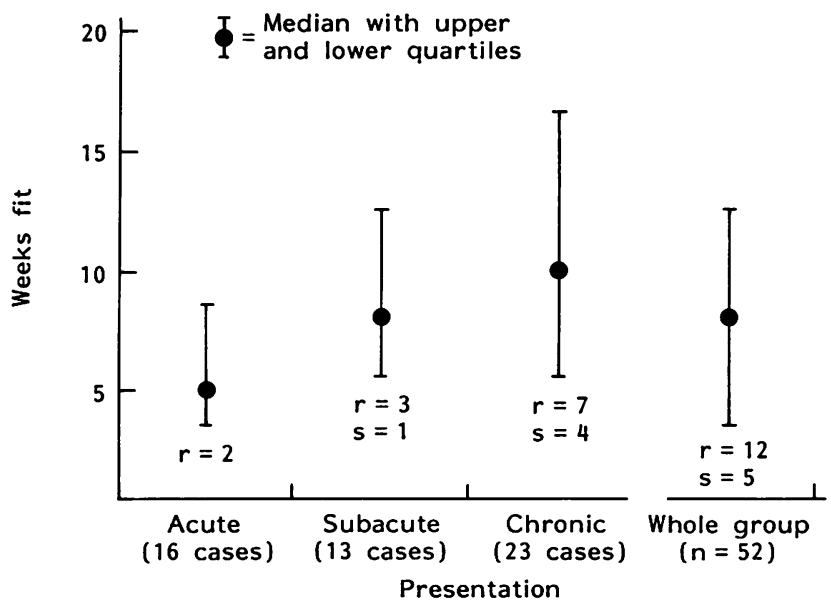

Figure 3. Return to sport where time to presentation of injury was known $(n=52)$ : $r$, no. of recurrences; $s$, no. of surgical cases; acute, 0-6 weeks; subacute 7-16 weeks; chronic, 17 weeks or more

(in respect of hamstring:quadriceps ratios) that the preferred and non-preferred legs may have a natural asymmetry which might affect injury. However, this paper showed no statistically significant difference between the two sides. Most interesting for conservative management is the high incidence of recurrence $(42 \%$ - see Table 5) and/or surgery $(37 \%)$ in the bilateral cases, suggesting that bilateral lesions should be considered for early surgery.

\section{Muscle incoordination}

Electromyographic evidence indicates that the quadriceps has virtually finished working before triceps surae contract and that rupture occurs when this mechanism is reversed ${ }^{18,26}$.

\section{Sport (Table 3)}

The majority of patients were runners though a number took part in several sports. The runners tended to present late, had a higher rate of surgical intervention and took longer to return to their sport. Other studies, 27, 28 support this finding, but as many athletes took part in more than one sport, care must be taken in assigning causative factors. Some authors found badminton had the highest incidence of

Table 2. Laterality and outcome

\begin{tabular}{|c|c|c|c|c|c|c|c|}
\hline \multirow{3}{*}{$\begin{array}{l}\text { Affected } \\
\text { side }\end{array}$} & \multirow[t]{3}{*}{ No. } & \multirow{3}{*}{$\begin{array}{l}\text { Average } \\
\text { time to } \\
\text { recovery } \\
\text { (weeks) }\end{array}$} & \multicolumn{4}{|c|}{ Treatment } & \multirow{3}{*}{$\begin{array}{l}\text { Outcome } \\
\text { unknown }\end{array}$} \\
\hline & & & \multicolumn{2}{|c|}{ Operative } & \multicolumn{2}{|c|}{ Non-operative } & \\
\hline & & & No. & $\%$ & No. & $\%$ & \\
\hline $\begin{array}{l}\text { Right } \\
\text { Left } \\
\text { Bilateral }\end{array}$ & $\begin{array}{l}24 \\
36 \\
19\end{array}$ & $\begin{array}{l}10(2-28) \\
10.5(2-32) \\
13.5(2-40)\end{array}$ & $\begin{array}{l}1 \\
3 \\
7\end{array}$ & $\begin{array}{r}4 \\
8 \\
37\end{array}$ & $\begin{array}{r}17 \\
22 \\
7\end{array}$ & $\begin{array}{l}71 \\
61 \\
37\end{array}$ & $\begin{array}{r}6 \\
11 \\
5\end{array}$ \\
\hline
\end{tabular}

* Because of recurrent injury, uncertain recovery times 
Table 3. Sports in which the 83 athletes participated

\begin{tabular}{lrr}
\hline Sport & No. & $\%$ \\
\hline Single sport athletes & & \\
Distance running & 24 & 43 \\
Track running & 14 & 25 \\
Tennis & 3 & 5 \\
Rugby & 3 & 5 \\
Gym & 3 & 5 \\
Squash & 2 & 4 \\
Football & 2 & 4 \\
Ballet & 2 & 4 \\
Badminton & 1 & 2 \\
School (variety of activities) & 1 & 2 \\
Hockey & 1 & $101^{*}$ \\
Total & 56 & \\
\hline
\end{tabular}

Distance events included: marathon; road running; hill walk and fells; cross country; steeplechase.

Track running included $100 \mathrm{~m}$ to $5000 \mathrm{~m}$ ( \pm hurdles).

Where more than one sport was involved, these included rowing, golf, aerobics, circuit and weight training and lacrosse

* Percentages do not sum to 100 due to rounding

Achilles tendon rupture ${ }^{29,30}$. The selectivity of the clinic must also be considered, plus the fact that some sports may produce TAP rather than rupture.

\section{Shoe problems ${ }^{31}$}

The Achilles tab or protector, as some shoe companies still call it, appears to have been cut down, yet new designs with an apparent dip in the tab are often as high as before. This tab can be hard and unbending and this tendency can be magnified by lace holes that are made further round the outer sides of the uppers so that when the laces are tightened the heel tab is drawn even tighter on to the Achilles tendon. All of this leads to increased contact pressure by the shoe on to the Achilles tendon. Broken heel counters precipitate excess pronation, thus increasing obliquity of tendo Achillis (TA) loading. These features were all dealt with individually in the clinics but not recorded in detail.

\section{Time to presentation (Figure 3)}

The earlier the patient presented for treatment the faster the recovery. However, the tendency to recurrence suggests that more time must be spent on eliminating the causative factors even after apparent recovery has been obtained. Several patients had had recurrent lesions present over several years and a pattern of running through pain, resting for 2 weeks, and then running again was common. Most athletes who recovered with conservative treatment settled over a 16-week course, suggesting that surgery after 8 weeks as proposed by Clancy ${ }^{17}$ is not mandatory. Certainly chronic cases would respond to conservative measures but several were operated upon.

Clancy ${ }^{17}$ has defined an acute lesion as presenting within 2 weeks, subacute within 6 weeks and those over this as chronic. A redefinition of acute as 0-6 weeks, subacute as $7-16$ weeks, and chronic as after 16 weeks, is proposed as more realistic on the basis of this study.

\section{Steroid treatment and recurrence (Tables 4 and 5)}

Of those treated with steroid injections, $43 \%$ had recurrences compared to $16 \%$ of the non-steroid group. The steroid-treated group contained $67 \%$ of severe injuries compared to $37 \%$ in the non-steroid group. In the steroid-treated group $43 \%$ of the injuries had presented after six months with symptoms, compared with only $20 \%$ of the non-steroid group.

\section{Severity}

The severity of the lesion as measured by the hopping test did not make any difference to the time for recovery. The hopping test is mainly a guide to progress and may only reflect pain rather than the nature of the cause. However, the degenerative changes of the tendinopathy probably show by taking longer to move through the hopping tests on to a running regimen. Thus hopping tests are only a guide to severity and more objective assessment with the help of magnetic resonance imaging could be of value.

Table 4. Management and outcome

\begin{tabular}{|c|c|c|c|c|c|c|c|c|c|c|}
\hline \multirow[t]{3}{*}{ Treatment group } & \multirow[t]{3}{*}{ No. } & \multirow[t]{3}{*}{$\%$} & \multicolumn{2}{|c|}{ Recurrences } & \multicolumn{4}{|c|}{ Injury* } & \multicolumn{2}{|c|}{ Surgery } \\
\hline & & & \multirow[t]{2}{*}{ No. } & \multirow[t]{2}{*}{$\%$} & \multicolumn{2}{|c|}{ Severe } & \multicolumn{2}{|c|}{ Mild } & \multirow[t]{2}{*}{ No. } & \multirow[t]{2}{*}{$\%$} \\
\hline & & & & & No. & $\%$ & No. & $\%$ & & \\
\hline $\begin{array}{l}\text { Steroid } \\
\text { Non-steroid } \\
\text { Advice only } \\
\text { No data }\end{array}$ & $\begin{array}{r}30 \\
49 \\
2 \\
2\end{array}$ & $\begin{array}{c}36 \\
59 \\
2.5 \\
2.5\end{array}$ & $\begin{array}{r}13 \\
8\end{array}$ & $\begin{array}{l}43 \\
16\end{array}$ & $\begin{array}{l}20 \\
18\end{array}$ & $\begin{array}{l}67 \\
37\end{array}$ & $\begin{array}{r}7 \\
21\end{array}$ & $\begin{array}{l}23 \\
43\end{array}$ & $\begin{array}{l}8 \\
3\end{array}$ & $\begin{array}{r}27 \\
6\end{array}$ \\
\hline \multicolumn{11}{|c|}{$\begin{array}{l}\text { Recovery time } \\
\text { No. recorded } 52 \\
\text { Weeks to fitness mean(range) } 11(2-40)\end{array}$} \\
\hline
\end{tabular}

* Severity not noted in 13 cases 


\section{Surgery (Table 4)}

The incidence of surgery was higher in the steroidtreated group. Repair of partial ruptures, curettage of areas of degeneration, and tenolysis of the adherent peritendon, are the common approaches ${ }^{5}$ though $14 \%$ recurred and $30 \%$ returned to match fitness only after six months ${ }^{5}$. The complications of skin necrosis, scar hypertrophy, infection and rerupture are reported and the risks of anaesthesia and pulmonary embolus should be considered. Indications for operation are considered later.

\section{Achilles tendon rupture}

One case occurred in an elite track and field athlete with a chronic history of TAP over 2 years, and the most recent episode of 3 weeks' duration had totally curtailed training. Severe bilateral mixed lesions were diagnosed, the right worse than the left. The athlete was unable to walk without discomfort and the final Olympic selection trials were 12 weeks away. Treatment comprised $1 \mathrm{ml}$ of hydrocortisone plus $1 \mathrm{ml}$ xylocaine infiltrated around each peritendon. By 8 weeks the athlete had progressed to high knee running on the rehabilitation ladder but due to an imminent trial jumped the ladder to fast sprints and suffered a left-sided recurrence. A further $1 \mathrm{ml}$ of hydrocortisone was given to the left paratenon and laser and physiotherapy to the right. Three weeks later, after a sprint session, the right tendon was diagnosed as ruptured by Simmonds'/Thompson's squeeze test and the needle test ${ }^{32,33}$ but as it was repaired using the closed Ma technique ${ }^{34}$ no confirmation of partial or total rupture was obtained. The left paratenon at open operation was found to be thickened and was stripped but no rupture was found.

\section{Discussion}

\section{Steroids}

In an attempt to look for reasons why the Achilles tendon ruptures, a number of well known 'studies' are quoted as 'proving' that local steroid injections are implicated ${ }^{35-40}$. In most of these studies the cases referred to were anecdotal. There were no trials, no

Table 5. Management of recurrences

\begin{tabular}{|c|c|c|c|c|c|c|}
\hline \multirow{2}{*}{$\begin{array}{l}\text { Side of } \\
\text { presentation }\end{array}$} & \multicolumn{2}{|c|}{ Recurrences } & \multicolumn{2}{|c|}{$\begin{array}{l}\text { Resolved } \\
\text { surgically }\end{array}$} & \multicolumn{2}{|c|}{$\begin{array}{c}\text { Resolved } \\
\text { conservatively }\end{array}$} \\
\hline & No. & $\%$ & No. & $\%$ & No. & $\%$ \\
\hline $\begin{array}{c}\text { Both sides } \\
n=19\end{array}$ & 8 & 42 & 7 & 87 & 1 & 14 \\
\hline $\begin{array}{l}\text { Left or right side } \\
\text { involved } \\
n=60\end{array}$ & 13 & 22 & 4 & 31 & 9 & 69 \\
\hline${ }^{*}$ Total $=79$ & 21 & 27 & 11 & 52 & 10 & 48 \\
\hline
\end{tabular}

* Side not recorded in four cases

$P=0.016$ (Fisher's exact test): probability of surgery in bilateral versus unilateral lesions consideration of other causative factors was made and most cases involved chronic lesions. The following two critics are not selective but indicative. Subotnick ${ }^{41}$ states ' $16 \%$ of 338 cases had steroids...', two of these 54 cases ruptured $(3.7 \%)$, '...therefore steroids are not used'. However, in the same paper four other cases of total rupture and no steroids plus six other cases of partial rupture and no steroids requiring surgery are presented (10 ruptures in 284 cases $=3.5 \%$ ). Helal $^{42}$ quotes $7 \%$ of those injected with steroids rupture', however this article gives no back-up figures of a trial or references for this figure. Only one paper $\left(\mathrm{DaCruz}^{43}\right)$ reporting a trial or a series, as opposed to case reports, was found, and that presented no ruptures. Leach and James also report no ruptures in their patients with Achilles tendons injected with steroids ${ }^{44}$. Our one case of rupture occurred 11 weeks after one paratenon injection but the tendon which had been injected twice showed no rupture. This would constitute a $3 \%$ rupture rate. A literature search shows a paucity of clinical evidence that steroids 'cause' Achilles tendon ruptures and some of the assumptions are hard to appreciate in statistical terms.

No papers were found reporting the rate of rupture of non-steroid treatment of Achilles tendons, yet several papers report ruptures as having occurred in these cases $^{27}$ but compare them to their total consultations as opposed to a percentage of Achilles tendon injuries ${ }^{24}$. Thus no comparison can be made between a 'normal' spontaneous rupture rate which obviously exists and steroid-induced ruptures, and it may well be that there is no difference.

There remains incomplete understanding of Achilles tendon disorders and the action of steroids. Histological changes of Achilles tendinopathy show mucoid, hyaline, myxoid and fibrinoid degeneration with giant cell infiltrate and foci of cell infiltration, while macroscopic changes of fibrillation, cleavage, 'tissue paper' tears and focal degeneration ${ }^{5,17}$ suggest that steroids which are anti-inflammatory have no logical place in the treatment of tendinopathy, indeed diminution of tensile strength may be produced for 2 to 3 weeks $s^{45-50}$. On the other hand pure peritendinitis $^{51}$ shows an inflammatory response ${ }^{6}$ which does respond clinically to steroids.

Ljunqvist $^{21}$ suggested that steroid injections are not aetiological in TA rupture. Many animal experiments show that the effects of high doses are not applicable to doses administered to the human tendon. Some experiments show that steroids initially weaken the tendon ${ }^{45-49}$. Kennedy and Baxter Willis ${ }^{50}$ showed that physiological doses of steroid into a rabbit tendon weakened it significantly for up to 2 weeks, but Oxlund ${ }^{52}$ found rat tendons to be stronger and stiffer after 24 and 55 days of steroidal treatment. He suggested this was due to steroid action on the elastic component and that the viscous properties remained unchanged, in agreement with Vogel's findings ${ }^{53}$. Human and animal fibroblasts can respond differently to steroids ${ }^{54}$, suggesting that extrapolation of animal experiments to humans must be viewed with caution.

Clinicians differ as to whether steroids should be used in TA injuries ${ }^{55,56}$. Hamilton and many other 
authors state that steroids should never be used even around the tendon, but their papers do not present evidence to support this fact and it appears to be the reiteration of dogma. Renstrom states that steroids can be injected around the tendon in chronic cases and several authors quote a maximum of two injections ${ }^{41}$, again on little scientific evidence. The results above suggest that the steroid-treated group returned no faster to fitness though a reduced morbidity, especially of morning pain and stiffness, appears to be common. Subotnick ${ }^{41}$ suggests oral rather than local steroids should be used, presumably on the basis that intralesional steroids have longer half lives than orally administered steroids ${ }^{57}$, and yet one of the aims of local therapy is to minimize systemic side effects. Long-term systemic steroids may promote TA rupture ${ }^{8-59}$ but the underlying diseases for which long-term steroids are prescribed have in their own right been implicated ${ }^{38}$.

\section{Management of TA lesions}

It is possible that TA lesions are a continuum ${ }^{3}$ from pure peritendinitis at one end to complete rupture at the other, while in the centre are mixed lesions, with peritendinous adhesions and tendon degeneration or partial rupture existing in different proportions. This paper and that of DaCruz et al. ${ }^{43}$ show no overall benefit from steroids given to the whole spectrum of the continuum. Indeed, most clinicians give steroids to the chronic cases that present late and with lesions so fibrotic that they usually recur and come to surgery, but give no steroids to the early presenters whose potential adhesions may be aborted. Clinical observations suggest marked improvement with steroid infiltration, reducing visual analogue pain scores of $8 / 10$ to $2 / 10$ in 1-2 weeks, and morning pain or pain on the stairs being abolished. Surgery itself does not always return an athlete to full activity and side effects have been reported. The costs of surgical treatment also have to be considered.

It should be remembered that local steroid injections only prevent or reduce the inflammation and adherent fibrosis of peritendinitis, but do nothing for the degenerative changes of tendinopathy. Once the history of morning pain or improvement over the day, or with activity, has gone then steroids are unlikely to contribute further. However, this morbidity itself may be the most significant factor for some patients. Friction massage, self-administered or by physiotherapy, may still help. It has been assumed that steroids have caused TA rupture whereas the steroid may, by reducing the pain of the peritendinitis, expose the underlying undiagnosed partial rupture to actual diagnosis and overload ${ }^{26}$ during exercise. This overload of an already present partial tear may lead to total rupture. It may be possible to visualize this partial tear by magnetic resonance imaging before treatment is started ${ }^{60}$, though until now this has not been the case. Thus, once the adherent peritendinitis has been treated, it is vital that carefully controlled rehabilitation is maintained during recovery to prevent overload of the compromised tendon. Failure to relieve symptoms or advance up the rehabilitation ladder should become considerations for surgery.

A proposed treatment regimen is summarized in Table 6.

\section{Conclusion}

The causes of TA lesions are multifactorial and the lesion itself may exist along a continuum from peritendinitis to complete rupture. Future prospective trials are required with magnetic resonance imaging and clinical diagnostic criteria to differentiate the continuum and the many contributing influences noted in its analysis. When comparing management of TAP it is important to remember that it may be possible to return to some sports activities before others and that sports themselves may have a different end point for match fitness. Steroids appear to help recovery from morbidity and in some individuals promote rapid return to activities, yet overall do not contribute to faster return to match fitness. It appears they are safe but more accurately

Table 6. Proposed treatment regimen

\begin{tabular}{|c|c|c|c|}
\hline $\begin{array}{l}\text { Laterality } \\
\text { (uni or bilateral) }\end{array}$ & $\begin{array}{c}\text { Age } \\
\text { (young or old) }\end{array}$ & $\begin{array}{l}\text { Patient } \\
\text { (active or inactive) }\end{array}$ & Treatment \\
\hline \multicolumn{4}{|c|}{ Chronic combined lesion (17 weeks or more) } \\
\hline b & y/o & a & \multirow{4}{*}{$\begin{array}{l}\text { Surgery, rehabilitation } \\
\text { Surgery, rehabilitation } \\
\text { \{teroids or physiotherapy to reduce morbidity, rehabilitation } \\
\text { Surgery if fails to progress or recurs }\end{array}$} \\
\hline $\mathbf{u}$ & $y$ & a & \\
\hline$u / b$ & y/o & $\mathbf{i}$ & \\
\hline $\mathbf{u}$ & 0 & a & \\
\hline \multicolumn{4}{|c|}{ Subacute combined lesion (7-16 weeks) } \\
\hline b & y/o & a & $\begin{array}{l}\text { Surgery } \\
\text { Steroids or physiotherapy if declines } \\
\text { Rehabilitation }\end{array}$ \\
\hline $\mathbf{u}$ & y/o & a & $\begin{array}{l}\text { Steroids or physiotherapy for morbidity } \\
\text { Rehabilitation }\end{array}$ \\
\hline$u / b$ & y/o & i & $\begin{array}{l}\text { Surgery if fails to progress } \\
\text { Steroids or physiotherapy, rehabilitation }\end{array}$ \\
\hline \multicolumn{3}{|c|}{ Acute combined lesion (up to 6 weeks) } & $\begin{array}{l}\text { Steroids and/or physiotherapy for peritendinitis } \\
\text { Rehabilitation for tendinitis }\end{array}$ \\
\hline \multicolumn{3}{|c|}{ Acute peritendinitis } & Steroids or physiotherapy \\
\hline
\end{tabular}


assessed trials are needed. It cannot be said conclusively that steroids 'cause' TA ruptures. They should be used in the paratenon where they settle inflammation but not in the tendon where they have no beneficial influence on degenerative pathology, and they should be used earlier rather than later in TAP.

\section{References}

1 Barfred T. Achilles tendon rupture. Acta Orthop Scand 1973; 44(Suppl 152): 126.

2 Lennox DW, Wang GJ, McCue FC, Stamp WG. The operative treatment of Achilles tendon injuries. Clin Orthop 1980; 148: 152-5.

3 Skeoch DU. Spontaneous partial ruptures of the tendo Achilles. Am J Sports Med 1981; 9: 20-2.

4 Gould N, Korson R. Stenosing tenosynovitis of Pseudosheath of tendo Achilles, Foot Ankle 1980; 1: 179-87.

5 Williams JGP. Achilles tendon lesions in sport. Sports Medicine 1986; 3: 114-35.

6 Kvist M, Jarvinen M. Clinical, histochemical and biochemical features in repair of muscle and tendon injuries. Int J Sports Med 1982; 3: 12-14.

7 Read M, Wade P. Sports Injuries: a unique guide to self diagnosis and rehabilitation. London: Breslich and Foss, 1984: 112-15.

8 Tunstall-Pedoe D. Sports injuries: cardiological problems. $\mathrm{Br} \mathrm{J}$ Hosp Med 1983; 29: 213-20.

9 McKenzie DC, Clement DB, Taunton JE. Running shoes, orthotics and injuries. Sports Medicine 1985; 2: 334-47.

10 Williams JGP. Overuse Injury. Dissertation for Degree of Doctor of Medicine. Cambridge University, 1984.

11 Pillet J, Alboret P. La rupture du tendon d'Achille. Med Sport 1972; 46: 15-22

12 Nillius SA, Nilsson BE, Westlin NE. The incidence of Achilles tendon rupture. Acta Orthop Scand 1976; 47: 118-21.

13 Robert L, Robert B, Robert AM. Molecular biology of elastin as related to aging and atherosclerosis. Exp Gerontol 1970; 5: 339-56.

14 Ippolito E, Postacchini F, Puddu G. Le alterazione strutturali del tendine di Achille. Med Sport 1973; 27: 258.

15 Riede D. Beitr Orthop Traumatol 1966; 13: 617. Cited in Cargill A. Closed rupture of the Achilles tendon. Br J Hosp Med 1976; 16: 524-33.

16 Lea RB, Smith L. Non-surgical treatment of tendo-Achilles rupture. J Bone Joint Surg [AM] 1972; 54-a: 1398.

17 Clancy WG. Tendinitis and plantar fasciitis in runners; In: $D^{\prime}$ Ambrosia $R$, Drez $D$, eds. Prevention and Treatment of Running Injuries, Thorofare, New Jersey: Charles B Slack, 1982: 77-88.

18 Arner O, Lindholm A. Subcutaneous rupture of the Achilles tendon. Acta Chir Scand 1959; Suppl. 239.

19 Hooker $\mathrm{CH}$. Rupture of the tendo Achilles. J Bone Joint Surg [B] 1963; 45B: 360-3.

20 Smart GW, Taunton JE, Clement DB. Achilles tendon disorders in runners: a review. Med Sci Sports Exerc 1980; 12 (4): $231-43$

21 Ljungqvist R. Subcutaneous partial rupture of the Achilles tendon. Acta Orthop Scand 1968; Suppl 113: 1-86.

22 Clement DB, Taunton JE, Smart GW. Achilles tendinitis and peritendinitis - etiology and treatment. Am J Sports Med 1984; 12(3): 179-85.

23 Jones SM, Robertson JA. Subtalar biomechanical evaluation in tendo achilles lesions. Presentation at BASM conference, Birmingham 1984. Br I Sports Med 1985; 19: 53 (Abstract).

24 Hattrup SJ, Johnson KA. A review of ruptures of the Achilles tendon. Foot Ankle 1985; 6 (1): 34-8.

25 Read M, Bellamy M. Comparison of hamstring quadriceps, isokinetic strength ratios and power in tennis, squash and track atheletes. $\mathrm{Br}$ J Sports Med 1990; 24: 178-82.

26 Distefano GJ, Nixon J. Ruptures of the Achilles tendon. J Sports Med Phys Fitness 1973; 34-7.

27 Fox JM, Blazina ME, Jobe FW et al. Degeneration and rupture of the Achilles tendon. Clin Orthop 1975; 107: 221-4.

28 Devereux MD, Lachman SM. Athletes attending a sports injuries clinic: a review. $\mathrm{Br} J$ Sports Med 1983; 17: 137-42.
29 Wills CA, Washburn S, Caiozzo V, Prietto C. Achilles tendon rupture: a review of the literature comparing surgical versus non-surgical treatment. Clin Orthop 1986; 207: 156-63.

30 Welsh RP, Clodman J. Clinical survey of Achilles tendonitis in athletes. Can Med Assoc J 1980; 122: 193-5.

31 Sperryn PN. Sport and Medicine. London: Butterworths, 1983: 241-5.

32 Thompson TC, Doherty JH. Spotaneous rupture of tendon of Achilles: a new clinical diagnostic test. I Trauma 1962; 2: 126-9.

33 O'Brien $T$. The needle test for complete rupture of the Achilles tendon. J Bone Joint Surg [Am] 1984; 66-A: 1099-1101.

34 Ma GW, Griffith TG. Percutaneous repair of acute closed ruptured Achilles tendon: a new technique. Clin Orthop 1977; 128: $247-55$.

35 Melmed EP. Spontaneous bilateral rupture of the calcaneal tendon during steroid therapy. J Bone Joint Surg [Br] 1965; 47-B: $104-5$.

36 Unverferth LJ, Olix ML. The effect of the local steroid injections on tendon. J Sports Med 1973; 1: 31-7.

37 Lee HB. Avulsion and rupture of the tendo calcaneus after the injection of hydrocortisone. $\mathrm{Br}$ Med J 1957; ii: 395.

38 Halpern A, Horowitz B, Nagel D. Tendon ruptures associated with corticosteroid therapy. West J Med 1977; 127: 378-82.

39 Ismail AM, Balakrishman R, Rajakumar MK. Rupture of the patellar ligament after steroid infiltration. J Bone Joint Surg [Br] 1969; 51-B: 503-5.

40 Smaill GB. Bilateral rupture of Achilles tendons. $\mathrm{Br}$ Med J 1961; ii: 1657-8.

41 Subotnick S, Sisney P. Treatment of Achilles tendinopathy in the athlete. I Am Podiatr Med Assoc 1986; 76: 552-7.

42 Helal B. Achilles heel cord. Clin Sports Med 1989; 1: 17-28.

43 DaCruz DJ, Geeson M, Allen MJ, Phair I. Achilles paratendinitis: an evaluation of steroid injection. Br J Sports Med 1988; 22: $64-5$.

44 Leach $\mathrm{R}$, James $\mathrm{S}$, Wasilewski $\mathrm{S}$. Achilles tendinitis. Am J Sports Med 1981; 9: 93-8.

45 Carstam N. Acta Chir Scand 1953; Suppl. 182. In: Berkin CR. Effects of cortisone on the healing of tendons in rabbits. Proc $R$ Soc Med 1955; 48: 610-13.

46 Balasubramanian $P$, Prathap $K$. The effect of injection of hydrocortisone into rabbit calcaneal tendons. J Bone Joint Surg [Br] 1972; 54-B: 729-34.

47 Berkin CR. Effects of cortisone on the healing of tendons in Rabbits. Proc R Soc Med 1955; 48: 610-13.

48 Gonzalez RI. Experimental tendon repair within the flexor tunnels. J Bone Joint Surg [Am] 1953; 35-A: 991-1002.

49 Wrenn R, Goldner J, Markee J. An experimental study of the effect of cortisone on the healing process and tensile strength of tendons. J Bone Joint Surg [Am] 1954; 36-A: 588-601.

50 Kennedy JC, Baxter Willis R. The effects of local steroid injections on tendons: a biomechanical and microscopic correlative study. Am I Sports Med 1976; 4: 11-21.

51 Puddu G, Ippolito E, Postacchini F. A classification of Achilles tendon. Am J Sports Med 1976; 4: 145-50.

52 Oxlund $\mathrm{H}$. Changes in connective tissues during corticotrophin and corticosteroid treatment. Dan Med Bull 1984; 31: 187-206.

53 Vogel HG. Correlation between tensile strength and collagen content in rat skin: effect of age and cortisol treatment. Connect Tissue Res 1974; 2: 177-82.

54 Priestly GC, Brown JC. Effects of corticosteroids on the proliferation of normal and abnormal human connective tissue cells. Br I Dermatol 1980; 102: 35-41.

55 Hamilton WG. Foot and ankle injuries in dancers. Clin Sports Med 1988; 7: 155-8.

56 Renstrom P, Johnson RJ. Overuse injuries. Sports Medicine 1985; 2: 316-33.

57 Goodman Gilman JA, Goodman M, Gilman G, eds. The Pharmacological Basis of Therapeutics. New York: Macmillan, 1980.

58 Price AE, Evanski PM, Waugh TP. Bilateral simultaneous Achilles tendon ruptures. Clin Orthop 1986; 213: 249-50.

59 Cowan MA, Alexander S. Simultaneous bilateral rupture of Achilles tendons due to triamcinolone. $\mathrm{Br}$ Med J 1961; i: 1658.

60 Briand B, Husson J, Rochecongar A et al. Tendinitis: preliminary evaluation with MRI and soft-tissue radiography. Acta Orthop Scand 1988; 59 Suppl 227: 69. 